\title{
Crisis Management by Criminal Proceedings in the Conditions of COVID-19 Pandemic
}

\author{
Submitted 06/06/20, 1st revision 23/07/20, 2nd revision 19/08/20, accepted 15/09/20 \\ Veronika V. Kolesnik ${ }^{1}$, Irina V. Kolesnik ${ }^{2}$, Yana B. Getman ${ }^{3}$, Natalia V. \\ Fedorenko $^{4}$, Nadezhda A. Kovtun ${ }^{5}$, Julia V. Fedorenko ${ }^{6}$

\section{Abstract:}

Purpose: The lack of due consideration to opportunities of crisis management in the criminal procedure sphere led to essential failures in implementation of criminal justice. On the basis of the available ideas of crisis management authors highlighted their vision of the specified institute to open the directions of its application in criminal proceedings in the conditions of spread of new coronavirus infection of COVID-19.

Design/Methodology/Approach: The complex of methods general (dialectic), general scientific (the analysis, synthesis, deduction, induction, system approach, extrapolation, analogy, comparison, system approach, abstraction, a specification, idealization, etc.), specific scientific character is successfully applied to achieve the goal of the study.

Findings: Authors consistently analyze crisis situations, content of crisis management and its opportunity in criminal proceedings. Arguments about the outdated nature of criminal proceedings in general and the criminal procedure law in particular in response to crimes during a digital era are specified. Conclusions on reformatting the patterns of criminal proceedings for the purpose of rapid response to crimes in crisis conditions are formulated.

Practical Implications: Strategic measures for smooth functioning of a criminal procedure system, including programs of crisis management by criminal proceedings in various crisis situations and also methodical recommendations to them are offered.

Originality/Value: Modern realities revealed not readiness of criminal proceedings for response to crimes in crisis conditions. This agenda existed earlier, however, in the conditions of economic, financial and political crises proved not fully. Epidemiological crisis showed not suitability of a criminal procedure system to expeditious and appropriate protection of the

${ }^{1}$ Candidate of legal science, associate professor of civil law department "Russian state University of justice”, Rostov branch, Rostov-on-Don, Russian Federation, nikkipohta@mail.ru;

${ }^{2}$ Doctor of law, associate professor, professor of civil law department "Russian state University of justice” Rostov branch, Rostov-on-Don, Russian Federation.

${ }^{3}$ Candidate of legal science, candidate of economical science, associate professor, professor of civil law department "Russian state University of justice" Rostov branch, Rostov-on-Don, Russian Federation.

${ }^{4}$ Doctor of sociology, candidate of legal science, professor of civil process, of Rostov state University of Economics, Rostov-on-Don, Russian Federation.

${ }^{5}$ Senior Lecturer, Department of Civil Law, Rostov Branch of the Russian Federation Federal State Budgetary Educational Institution of Higher Education "Russian State University of Justice” Rostov branch, Rostov-on-Don, Russian Federation.

${ }^{6}$ Candidate of legal science, associate professor of civil process, of Rostov state University of Economics, Rostov-on-Don, Russian Federation. 
rights and legitimate interests of the persons and the organizations injured from crimes and also protection of the personality against illegal and insubstantial accusation, condemnation, restriction of human rights and freedoms.

Keywords: Crisis management, criminal proceedings, digital era, economic crisis, epidemiological crisis, COVID-19.

JEL codes: H12, G01, K41.

Paper type: Research article.

\section{Introduction}

Crisis, mainly, can be understood in three meanings: as "a sharp, drastic change in something", as "the periodic relative overproduction of goods in capitalist society leading to frustration of economic life, unemployment and poverty of workers" or as "a difficult, difficult situation" (Ojegov, 2010). The specified meanings deeply got into all spheres of human, public, state activity. Economic, financial, currency, political, military, power, ecological, social, demographic, - and many other types of crises exist and stand out scientists and practicians. Possibly, there are no such spheres in which crisis could not prove. Everything recognizes that the difficulty of situation can arise in any environment, in any activity, at any time. In it the universal line of crisis also consists - in its generality and inclusiveness in manifestations (Gusev, 2013).

Certainly, the economic sphere mostly is associated with crises. The most large-scale economic crises of Russia (1998, 2008-2010, 2014-2015, 2019-2020) confirm the specified circumstance. Devaluation of national currency, commodity and financial deficiencies, growth of inflation and unemployment, decrease in consumer demand, economic downturn, growth of level of poverty and decrease in real income of the population is only a part of negative consequences which were apprehended by residents of Russia. It is confirmed also by statistics on consequences of economic crises, and population way of life in a post-crisis situation (Pashintseva, 2010).

In these conditions, the search of an exit from a crisis became one of the major tasks the country leaders, the enterprises, financial and banking institutions and scientists are facing. Development of crisis management patterns acted primary at implementation of strategic planning of business activity of companies, institutions and states. Since 1990 the development got such scientific and applied nature of economy as crisis management. The emergence is caused by the crises, no matter how corny it sounds. Crisis management represents development and application of forms, methods and the funds allocated for recognition of the predicted crisis situations, their identification, neutralization and elimination of consequences of crisis. In other words, it is a certain system of measures for diagnostics, prevention, neutralization, overcoming the crisis phenomena and their backgrounds at all levels of economy of 
the enterprise. However, crisis management was not limited to the field of economy, as well as variations of the crisis phenomena in general are not limited.

\section{Theoretical Foundations of the Study}

Scientific literature is oversaturated with various works devoted to anti-crisis management as one of the areas of economic science. The degree of elaboration of this problem in general does not indicate its development in legal science, especially in criminal procedure law. Currently, insufficient attention has been paid to the problem of crisis management of legal processes. There are no publications on this subject in criminal procedure science. It remains only to build analogies, turn to related industries, extrapolate already known conclusions into an unexplored area. Obviously, such a situation cannot but affect not only the success of the anti-crisis management of the criminal process, but also the criminal proceedings in crisis situations.

The key is the study of the subject in dynamics, in the conditions of constant interaction of elements of a unified system of anti-crisis control of the criminal process, as well as taking into account the laws and contradictions revealed in this activity. Here we can distinguish such methods as general science (analysis, synthesis, deduction, induction, system approach, extrapolation, analogy, comparison, system approach, abstraction, concretization, idealization, etc.), private scientific (historical, legal-interpretive, legal-technical, formal-legal, statistical, etc.).

Previously, anti-crisis management in law or jurisprudence was not talked about. This is probably due to the fact that anti-crisis management in the generally accepted meaning implies a certain enterprise (institution) and its management in crisis conditions. We believe that in view of the fact that crisis situations directly affect the legal sphere and affect the quality of ensuring the rights and freedoms of a person and citizen, anti-crisis management can also be attributed to jurisprudence. Although the crisis in law-making and law-enforcement activities could be more provoked by other crises occurring in the state (for example, economic), the scale of its influence on an individual person, society and the state is very significant. The main feature of crises is uncertainty, which could lead to a variety of consequences (Afanasyev, 2016).

The new challenges of our time strongly point to this. Crises in the economy, social sphere, politics are increasingly reflected in law. Thus, the financial, economic and currency crises of the last decade have led to an increase in crime, especially economic crime, a decrease in the level of detection of crimes, an increase in riots, violations of public security and public order, etc. All this brings the legal mechanism for regulating public relations into the unknown, complicated situation, including criminal situation. Of course, there are typical scenarios of events related to social disorders and the spread of crisis manifestations, and they have been developed appropriate state response algorithms. Law enforcement institutions, depending on developing processes in society and the state, have tested mechanisms of enforcement. It is mainly 
about emergence of force majeure, emergency situations and the emergency rules entered on their basis and on the basis of the Federal constitutional law of 30.05.2001 No. 3-FKZ "On the State of Emergency" and other regulations. The special legal regime implies specificity in the activities of all bodies, organizations and institutions, regardless of the form of ownership, as well as a special procedure for the violation and application of means to ensure a state of emergency.

However, not all crisis situations fall under the state of emergency. It is probably more correct to note that such a regime often covers situations related to military-political crises. The lion's share of crises i.e. economic, financial, social, remains outside the special regime. But from the point of view of legal protection, the population suffers from deprivation as well.

\section{Results}

In 2020 quite reasonably it is possible to refer the crises connected with an epidemiological situation in the country and the world to this group of crisis situations. It is about extensive spread of new coronavirus infection (COVID-19) and its consequences. The reality which millions of people and governors of most the states faced worldwide, shows that epidemiological crisis could become the cause of an economic, social, political crisis and lead to the most negative consequences. This crisis situation visually showed weak readiness of a law-enforcement system for functioning in similar conditions. Most noticeably it was shown in the criminal procedure field in which the most important rights and freedoms of the person and citizen are affected. Reception and registration of statements (messages) about crimes, initiation of criminal proceedings, proceedings of investigative and other legal cases, application of measures of procedural coercion, including election of restraint measures, bringing a charge, drawing up accusatory the conclusion (the act, the resolution), judicial proceedings, adjudication, the appeal of proceeding decisions all this became extremely difficult in the conditions of a pandemic.

The first thing the population, law enforcement agencies and judicial authorities faced at introduction of restrictive measures without introduction of an emergency rule was the following:

1. Lack of regulation of reception and registration of statements and messages about crime in an electronic form.

2. Limitation in actions of the investigator at establishment of the bases for initiation of criminal proceedings.

3. Lack of regulation and practically impossibility of production of separate investigative and legal proceedings:

- interrogation of the person having symptoms of coronavirus infection in the remote mode;

- a confrontation between the persons having symptoms of coronavirus infection in the remote mode; 
- inspection of the scene in which restrictive measures are introduced;

- check in rooms in which the persons having symptoms of coronavirus infection and also contacting to these persons live;

- verifications of indications on the place with the person having symptoms of coronavirus infection and also in the area on which restrictive measures are introduced;

- examination of the person having symptoms of coronavirus infection;

- presentation for identification of the person having symptoms of coronavirus infection or to the persons having symptoms of coronavirus infection;

- an investigative experiment in the territory in which restrictive measures are introduced;

- survey and exhumation of the corpse which had symptoms of coronavirus infection.

4. Impossibility of extension of terms of preliminary investigation over the restrictive measures provided by the law.

5. Impossibility of full conducting court sessions on election of measures of restraint, extensions of their terms and also to pronouncement of judgments on criminal case, including the remote mode.

6. Lack of appropriate means of individual and collective protection of spread of new coronavirus infection and also a possibility of expeditious establishment of presence of the specified infection at and participants of criminal proceedings.

These and many other difficulties which law enforcement and judicial authorities faced at introduction of restrictive measures led to formation of a crisis situation in criminal proceedings in general and at implementation of criminal justice in particular. In spite of the fact that most law enforcement and judicial authorities continued to function practically in the normal mode, difficulties were faced in participation in criminal proceedings of other participants of criminal proceedings who are not officials and do not perform the duties established by the state on realization of purpose of criminal proceedings. The helplessness of all legal system was shown at the very beginning of distribution of a pandemic and at introduction of the most drastic restrictive measures. In such conditions, against the background of more than 1,5 months isolation, the legal authorities faced the non-working situation.

Obviously, similar situation not in the best way affected the quality of protection of the rights and legitimate interests of the persons and the organizations which suffered from crimes and also protection of the personality against illegal and insubstantial accusation, condemnation, restriction of its rights and freedoms. In spite of the fact that in mass media it was practically not reported about violations of the rights and freedoms of citizen in criminal proceedings, it was possible to be sure many times more, than usually. Their considerable part will be opened a little later - in the course of the appeal of the proceeding decisions connected with violation of the rights and freedoms, legitimate interests, procedural terms, etc. At the same time, probably the main share of such violations appeared only in connection with unpreparedness of a criminal procedure system to functioning in crisis conditions. We believe, the observed situation turned out to be a consequence of total absence of mechanisms of 
crisis management by criminal proceedings. Possibly, it also proceeds from discrepancy of the criminal procedure law with requirements of time - an era of digital technologies and also unpreparedness of law enforcement officials to carry out functions of criminal proceedings in such conditions.

Obviously, part of the problems will be solved by the modernization of the criminal procedure law in relation to digital society conditions, the other part will be the improvement of the grade of criminal procedure subjects, especially those representing the indictment power. In particular, there are scientifically based proposals on the procedure for individual proceedings with persons with a serious illness (Grigoriev and Kovalchuk, 2018).

Although the current criminal procedure law contains separate provisions that could be applied in certain crisis situations, it remains, from a digital point of view, extremely outdated. Thus, it contains rules governing:

- Features of witness interrogation by means of videoconferencing systems (Article 278.1 of the Code of Criminal Procedure of the Russian Federation);

- the possibility of the defendant voicing the last word using videoconferencing systems (Article 293 of the Code of Criminal Procedure of the Russian Federation);

- The possibility of participation of a convicted person in custody who has declared his or her wish to be present during the consideration of an appeal by means of videoconferencing systems (Code of Criminal Procedure, art. 389.12);

- possibility of the appellate court to investigate evidence using videoconferencing systems (Article 389.13 of the Code of Criminal Procedure of the Russian Federation); - the possibility of the convict's participation in the court hearing when resolving issues related to the execution of the sentence by using videoconferencing systems (article 399 of the Code of Criminal Procedure of the Russian Federation);

- the possibility of participation of the victim, his legal representative, representative in the court hearing when resolving issues related to the execution of the sentence by using videoconferencing systems (article 399 of the Code of Criminal Procedure of the Russian Federation);

- the possibility of participation of a person in custody or a convicted person serving a sentence of deprivation of liberty by using videoconferencing systems (Article 401.13 of the Code of Criminal Procedure of the Russian Federation);

- the possibility of submitting petitions, applications, complaints, submissions to the court in the form of an electronic document signed by the person who sent such a document by an electronic signature in accordance with the legislation of the Russian Federation (Article 474.1 of the Code of Criminal Procedure of the Russian Federation).

As we notice, the Code of Criminal Procedure of the Russian Federation does not contain any features of pre-trial proceedings: neither on the use of videoconferencing in the conduct of investigative and other procedural actions, nor on the implementation of anti-crisis mechanisms for managing the criminal process. The latter does not 
contain judicial proceedings. Also, not sufficiently convincing in this vein are the proposals for cyber investigators, replacement by information technologies of more subjects of investigation, about digital assistants of judges, about electronic criminal case (Zuev, 2018; Vlasova, 2018; Kuvychkov, 2016; Zuev and Nikitin, 2017; Kachalova and Tsvetkov, 2015; Grigoriev et al., 2019).

We believe that with such a criminal process in general and a criminal procedure law in particular, it is probably difficult to get out of crisis situations, but also to meet the requirements of the times. In the first part of the problem, even the introduction of a set of new standards will not solve the problem. In addition, the law cannot provide for all atypical cases of law enforcement. In this regard, we believe that it is necessary to develop a set of strategic measures for the smooth functioning of the criminal procedure system, which includes:

- A programme of anti-crisis management of the criminal process in the case of a state of emergency;

- A programme of anti-crisis management of the criminal process in the case of a crisis and in the absence of a state of emergency.

The latter should in turn include:

- Anti-crisis management of the criminal process in the case of an economic crisis;

- A programme of anti-crisis management of the criminal process in the case of a political crisis;

- A programme for crisis management of the criminal process in the case of an environmental crisis;

- A programme of anti-crisis management of the criminal process in the case of an epidemiological crisis.

At the same time, each program should include the development of methodological recommendations for both legislators and law enforcement officers, as well as for the population. In the specified programs and methodical recommendations, mechanisms of response of a criminal procedure system to crisis situations and also specific forms, methods and the funds allocated for recognition of the predicted crisis situations, their identification, neutralization and elimination of consequences of crisis have to be considered.

\section{Conclusions}

The crisis situation which arose in the period of COVID-19 pandemic visually showed weak readiness of a law-enforcement system for functioning in similar conditions. Most noticeably it was shown in the criminal procedure field in which the most important rights and freedoms of the person and citizen are affected. Reception and registration of statements (messages) about crimes, initiation of criminal proceedings, production of investigative and other legal proceedings, application of measures of procedural coercion, including election of measures of restraint, bringing a charge, 
drawing up accusatory conclusion (the act, the resolution), judicial proceedings, adjudication, the appeal of proceeding decisions - all this became extremely difficult in the conditions of a pandemic. Key problems which law enforcement authorities and the population faced:

- lack of regulation of reception and registration of statements and messages about crime in an electronic form.

- limitation in actions of the investigator at establishment of the bases for initiation of criminal proceedings.

- lack of regulation and practically impossibility of production of dividing investigative and legal proceedings:

- impossibility of extension of terms of preliminary investigation over the restrictive measures provided by the law on the basis of introduction.

- impossibility of full conducting court sessions on election of measures of restraint, extensions of their terms and also to pronouncement of judgments on criminal case, including the remote mode.

- lack of appropriate means of individual and collective protection of spread of new coronavirus infection and also a possibility of expeditious establishment of criminal proceedings' specified infection.

- limitation of institute of the appeal of legal proceedings and decisions.

Various violations in criminal proceedings appeared only in connection with unpreparedness of a criminal procedure system to functioning in crisis conditions. The observed situation turned out to be a consequence of total absence of mechanisms of crisis management by criminal proceedings. Possibly, it also proceeds from discrepancy of the criminal procedure law with requirements of time - an era of digital technologies and also unpreparedness of law enforcement officials to carry out functions of criminal proceedings in such conditions. Obviously, the part of the problem will be solved by modernization of the criminal procedure law in relation to conditions of digital society, other part - developing the skills of the subjects of criminal procedure activity in particular representing the accusatory power. However, it is not enough.

Though the existing criminal procedure law also contains separate provisions which could be applied in separate crisis situations, it remains extremely outdated from the digital point of view. It is offered to develop programs of crisis management by criminal proceedings in various crisis conditions and also methodical recommendations to them both for legislators and law enforcement officials, and for the population.

\section{References:}

Afanasyev, A.Yu. 2016. Legal uncertainty in the criminal procedure law of evidence as a corruptogenic factor. Jurisprudence and practice: Bulletin of the Nizhny Novgorod Russian Interior Ministry Academy, 1, 210-214. 
Grigoriev, V.N., Kovalchuk, L.B. 2018. About technical means of control at an extradition of the defendant who got sick with a serious illness. All-Russian criminological journal, $2,220-229$.

Grigoriev, V.N., Suhodolov, A.P., Ovanesyan, S.S., Spasennikova, M.G., Tyunkov, V.V. 2019. Digital information platforms as a legal regulation subject in the sphere of criminal proceedings. All-Russian criminological journal, 6, 873-883.

Gusev, A.B. 2013. Strategy of economic development of regions of Russia: system crisis and new economic space. Region economy, 4 (36), 220-237.

Kachalova, O.V., Tsvetkov, Yu.A. 2015. Electronic criminal case - the instrument of modernization of criminal proceedings. Russian justice, 2, 95-101.

Kuvychkov, S.I. 2016. Use in proof on criminal cases of information provided in electronic form. Ph.D. thesis, Nizhny Novgorod, 273.

Ojegov, S.I. 2010. Explanatory dictionary of Russian. Moscow, LLC Onyx Publishing House, 736.

Pashintseva, N.I. 2010. Effective official statistics key to the solution of problems of postcrisis development. Region economy, 2 (22), 178-189.

Vlasova, S.V. 2018. To a question of adaptation of the criminal procedure mechanism to digital reality. Library of the criminalist, Scientific journal, 1, 9-18.

Zuev, S.V. 2018. Digital environment of criminal proceedings: problems and prospects. Siberian legal messenger, 4, 118-123.

Zuev, S.V., Nikitin, E.V. 2017. Information technologies in the solution of criminal procedure problems. All-Russian criminological journal, 3, 587-595. 